Pak. J. Agri., Agril. Engg., Vet. Sci., 2020, 36 (1): 27-33

ISSN: 1023-1072 (Print), ISSN: 2663-7863 (Online)

https://doi.org/10.47432/pjaaevs.2020.36.1.5

\title{
REVEALED COMPARATIVE ADVANTAGE OF SELECTED AGRICULTURAL COMMODITIES OF PAKISTAN
}

\author{
A. Ali ${ }^{1 *}$, W. Akhtar ${ }^{2}$, S. Ahmad ${ }^{3,4}$ and C. Honghua ${ }^{1}$ \\ ${ }^{1}$ College of Economics and Management, China Agricultural University, \\ No. 17 Qing Hua Lu, Haidian district, 100083, Beijing P. R. China \\ ${ }^{2}$ Social Sciences Research Institute (SSRI), NARC, Islamabad \\ ${ }^{3}$ College of Humanities and Development Studies, China Agricultural University, \\ No. 17 Qing Hua Lu, Haidian district, 100083, Beijing P. R. China \\ ${ }^{4}$ University of Agriculture, Faisalabad, Sub Campus Burewala, Punjab, Pakistan
}

\begin{abstract}
Since, Pakistan is bound to follow the international agreement drafted by WTO (World Trade Organization) to formulate trade policy which should be based on comparative and competitive advantages in the international economy, therefore the present study was designed to examine the specialization and competitiveness of Pakistan's major crops. For this purpose, Bela' Balassa's (1965) indexes of Revealed Comparative Advantage (RCA) and Revealed Symmetric Comparative Advantage (RSCA) were employed, and moreover, secondary data from reliable sources related to crops from 1980 to 2013 were extensively utilized. The major findings of this research study revealed that Pakistan has a strong comparative and competitive advantage in rice, onion, dates, mango, mangoesteen and guava during the period ranging from 1980 to 2013. Similarly, Pakistan has higher competitiveness in rice and mango at international level. Results also indicated that Pakistan has been facing disadvantages in potatoes during 1980 to 1997, and banana during 1980 to 2009, however, it was maintained but these vegetables/fruits have no competitiveness in the international market. The present study concludes that Pakistan has an excellent capability (being and agriculturally based economy) of higher growth of these products; therefore, these agricultural items could prove themselves a good source for Pakistan to earn higher foreign exchange.
\end{abstract}

Keywords: revealed comparative advantage, revealed symmetric comparative advantage, rice, onion, dates, mango, mangoes-teens, guava

\section{INTRODUCTION}

Trade is crucial for growth, and growth is necessary for poverty reduction. Many developing countries around the globe depend on agricultural production and its trade to sustain their respective economies. Pakistan is also one of them and it largely depends on the agricultural sector to sustain its economy. It has been minutely observed that the prices of the traditional agricultural commodities have been gradually declining over the past few years (Ruma, 2011; Yousaf, 2018). Now a days, various national economies are mutually interdependent to one another. It is very difficult to search a single example of a closed economy in the world. Now, many countries of the world are open economies. But the level of openness

*Corresponding author: asifalilakho94@gmail.com and closeness altogether differs from one country to another. Thus, no country is entirely self-sufficient. The term 'self-sufficiency' is used differently in many countries; but here it is used for the proportion of the commodities consumed to their total production (Vijayasri, 2013).

Pakistan is also one of the open economies which has gained enormous specialization in the production of different agricultural commodities like rice, potato, onion, banana, date, mango, mangos-teen and guava. The production of rice plays a vital role in furthering the national economy of Pakistan. Pakistan is the $3^{\text {rd }}$ largest exporter of rice (3800 thousand metric tons) in the world and shares $9.1 \%$ of total world rice exports (Ali, 2013). It is a major cash crop after cotton. Sindh and the Punjab provinces of Pakistan are the major rice producing regions, and it is a major source of employment for farming as well as non-farming communities of 
the rural areas (Akhtar, 2018; Tabasam, 2018). Basmati variety is one of the most popular varieties in Pakistan, known for its quality, aroma, and flavour all over the world.

After a long time, potato has acquired the status of a main crop in Pakistan both for the farming community and the consumers as well. Pakistan is the $12^{\text {th }}$ largest potato exporting country around the globe, and its share is $2.8 \%$ in the world potato export (Worldexport Com, 2019). According to FAO (2016). Pakistan is the world's $13^{\text {th }}$ largest exporter of potato which shares $2 \%$ of total world potato exports.

Onion is one of the oldest vegetable crops in the world. It is a crucial bulb vegetable crop, commercially grown in most countries of the world including Pakistan. It is consumed as green as well as in mature stages by everyone, and it protects humans from sunstroke and various other hazardous diseases. Pakistan is the world's $13^{\text {th }}$ largest producer and supplier of onions and its share is $1.4 \%$ in the world onion export (FAO, 2016; Workman, 2019).

Banana is a famous fruit crop of Pakistan. It is cultivated on 34,800 hectares with production of 154,800 tons. For its successful cultivation the soil and climatic conditions are favourable in Sindh province than that of the other provinces. The overall share of Sindh province alone in its cultivation is $87 \%$. Pakistan is the $37^{\text {th }}$ largest banana exporter of the world (Workman, 2019). Banana is mostly cultivated in Tando Muhammad Khan, Sanghar, Naushero-Feroze, Thatta, Hyderabad, Badin, Mirpurkhas, Tando Allahyar, Matiari and Shaheed Benazir Abad districts of the Sindh province of Pakistan.

Khairpur district of Sindh province is the major producer of dates. Being a most nutritive and energy providing food, it has an economic importance for Pakistan also (Ishtiaq et al., 1988). Dates are rich in energy due to high carbohydrates. It contains certain nutrients, minerals, proteins, fats, vitamins, etc. There are three main types of date cultivars named soft, semi-dry and dry cultivars (Selim et al., 1970). Pakistan is ranked the $3^{\text {th }}$ largest exporter of dates in the international market (Khadim, 2016).

Pakistan is the $2^{\text {nd }}$ major producer of mango with high international value. It is the mouthwatering fruit of summer season which is loved by all. Due to its taste, fragrance and high nutritional value it is also called "the king of all fruits". The uncontrollable temptation for the Pakistani mango lovers is its sweet taste and aroma which is not found anywhere else in the world, except Pakistan. Pakistan has the $5^{\text {th }}$ position in the mango producing countries of the world (FAO, 2016). Mango is mostly cultivated in Mirpurkhas, Hyderabad Thatta, Multan, Bahawalpur, Rahimyar Khan, Peshawar and Mardan districts of Sindh, Punjab and KP provinces of Pakistan, respectively. The climatic conditions of Sindh become warmer one month earlier than that of the Punjab province; which has given an advantage to Sindh province to grow and harvest early varieties of mango, before other provinces.

Trade is basically a worldwide transformation of commodities, inputs, and technology. Market of an output of a country escalates beyond national frontiers and may ensure better prices through exports. Those commodities, inputs and technology which are very expensive or not available here are imported through trade from other countries (Vijayasri, 2013). The weather of Pakistan is very favorable for the cultivation of several crops (fruits, vegetables, rice, cotton, etc.) (Akhtar et al., 2009). Rice, potato, onion, banana, dates, mango, mangos-teen and guava are Pakistan's most important food exports. Beside that these are best earning resources and have significant impact on export earnings.

Competitiveness and specialization of commodities using RCA analysis have already attempted, like Bakhshinejad and Zadeh, (2012) conducted a study on agricultural commodities in Iran considering the data of 2002-07, and identified five agricultural products (almond, apple, hazelnut, walnut and orange) as potential products for the economy of Iran. According to the WTO's agreement on Agriculture, trade policy in Pakistan should be based on CA, under which the members of WTO are required to make use the benefits of comparative and competitive advantage in the international economy, cumulative competition and forcing resources to be assigned more efficiently. Consequently, the authors of this study are hopeful that Pakistan is the country, which is blessed with multiple seasons, adequate canal water availability, fertile soil, and suitable topography which could lead to produce quality and quantity of various agricultural products but there is need to recognize the items. Since, $\mathrm{RCA}$ is an index which is utilised in international economics for analysing the advantage or disadvantage of a country in a certain category of goods or services (Balassa, 1965), this study was staged in a similar fashion, where the results regarding competitiveness and 
specialization of commodities will be helpful to generate recommendations for policymakers and concerned departments.

\section{MATERALS AND METHODS}

The present study is qualitative in its nature because it generally relies on the secondary data. It covers a period from 1980 to 2013. In order to meet the objective of the study, various reliable sources such as Economic Survey of Pakistan, Annual Plans of Pakistan, Food and Agriculture Organization (FAO) were mostly considered to collect secondary data. In addition, Revealed Comparative Advantage (RCA) and Revealed Symmetric Comparative Advantage (RSCA) indices were used for the analysis of selected agricultural commodities of Pakistan which are described as under:

\section{Revealed Comparative Advantage (RCA) Index}

Balassa's RCA index (1965) of revealed comparative advantage was used to measure the RCA in agriculture sector of Pakistan. Balassa's (RCA) is a method to measure competitiveness and specialization of countries in commodities which they have. An RCA index reveals the CA of a nation from its past trade data and can be calculated yearly. Furthermore, the trends in competitiveness of a commodity can also be identified.

\section{Standard RCA Balassa's Index}

$R C A i j t=\frac{\left(\frac{X i j t}{\sum X a t}\right)}{\left(\frac{X i w t}{\sum X a w t}\right)}$

Where,

Xijt represents country i's export of product $j$ in year t, Xiwt represents total world exports of product $\mathrm{i}$ in year $\mathrm{t}, \Sigma$ Xajt represents total exports in country $j$ in year $t$ and $\sum$ Xawt represents total world exports in year t.

When RCA is greater than 1 , it means that country $\mathrm{j}$ has a revealed comparative advantage on commodity i.

When RCA is less than 1 , it means that country $j$ has a revealed comparative disadvantage on commodity i.

\section{Revealed Symmetric Comparative Advantage (RSCA) Index}

To know the problem of upward-biased RCA index values, Laursen (1998) adjusts the RCA index to make it symmetric, such that the adjusted index values are between -1 and +1 . Dalum et al. (1998) also proposed a Revealed Symmetric Comparative Advantage index (RSCA) which enables symmetric index values of RCA ranging from -1 to +1 . Laursen (1998) identifies this index as RSCA is calculated using, following equation:

\section{$R S C A i j t=(R C A i j t-1) /(R C A i j t+1)$}

Positive and negative values of RSCA demonstrate a competitive advantage and disadvantage of exporting product $\mathrm{i}$ in country $\mathrm{j}$, where, RSCA is often interpreted as an index of specialization. These indices were used by several researchers (Balassa, 1989; Scott and Vollrath, 1992; Laursen, 1998; Ferto and Hubbard, 2004; Hsu and Wann, 2004) to determine comparative and competitive advantage. This study considered both Balassa's and Vollrath's indices in the analysis of comparative and competitive advantage of the Pakistan agriculture with respect to global trade.

\section{RESULTS AND DISCUSSION}

Rice is an important cash crop of Pakistan and it is a main exportable agricultural commodity among all the important commodities of Pakistan. Pakistan is the net exporter of rice (Akhtar et al., 2007). The results have exposed that the revealed comparative advantage of rice has increased over time during the period under analyses (1980-2013) and there was no any comparative disadvantage of rice from 1980 to 2013. There is also a chart (listed below) for selected agricultural commodities where one can observe the curve of rice (Sky-blue curve) which shows the fluctuations of rice product.

Pakistan has values of RCA less than one during 1980-81 to 1996-97 showing a revealed comparative disadvantage in potatoes, however Pakistan has experienced a revealed comparative advantage during 1997-98 as shown in Table 1. This implies that Pakistan has attained and maintained the level of comparative advantage in potatoes up to $2012-13$ as RCA indicating greater than 1 . Revealed comparative advantage and disadvantage of potatoes can be observed in Figure 1 through orange curve. Onion is also an important cash crop for farmers as well as among the main exportable horticulture products (Akhtar et al., 2013), therefore during the period Pakistan was net exporter of onion crop. Results of analysis exhibit that Pakistan shows comparative 
disadvantage RCA value less than 1 during 1990-93 and 1995-96. However, Pakistan gained comparative advantage in onion export in 1997 and maintained it up to 2012-13 where the value of RCA exceeds 1 which is also exposed in Figure 1 through the grey curve.

Again, banana is supposed to be a major fruit crop of Pakistan which is mostly grown in Sindh province of Pakistan. It is the world's $4^{\text {th }}$ largest fruit (Memon, 2015). Pakistan has no comparative advantage in banana because the values of RCA are less than one during 1980-81 to 2008-09 showing a revealed comparative disadvantage. Pakistan has started to gain a revealed comparative advantage since 2009-10
(Table 1) and could be observed the revealed comparative disadvantage of banana in the diagram. Revealed comparative advantage in banana has increased in recent years from 2009-10 (Figure 1). Pakistan is the $7^{\text {th }}$ largest producer of date fruit in the globe, where Khairpur district of Sindh province is the major producer of dates (Markhand et al., 2010). Pakistan is the net exporter of date. Therefore, results have exposed that the revealed comparative advantage of date fruit has increased over time during the period under study 1980-2013. It can be observed in Table 1 and Figure 1.

Table1. Revealed comparative advantage of selected agriculture commodities of Pakistan

\begin{tabular}{|c|c|c|c|c|c|c|}
\hline Year & Rice & Dates & $\begin{array}{l}\text { Mango, Mango-teens and } \\
\text { Guava }\end{array}$ & Banana & Onion & Potato \\
\hline $1980-81$ & 65.68 & 7.13 & 53.9 & 0.99 & 18.35 & 0.69 \\
\hline $1981-82$ & 71.13 & 30.94 & 59.3 & 0.96 & 12.25 & 0.44 \\
\hline $1982-83$ & 53.58 & 36.19 & 92.92 & 0.58 & 16.02 & 0.95 \\
\hline $1983-84$ & 76.51 & 46.01 & 54.9 & 0.46 & 7 & 0.33 \\
\hline 1984-85 & 52.85 & 46.48 & 31.55 & 0.46 & 6.65 & 0.5 \\
\hline $1985-86$ & 73.08 & 30.13 & 31.16 & 0.53 & 11.29 & 0.11 \\
\hline 1986-87 & 60.04 & 29.8 & 29.01 & 0.74 & 4.86 & 0.14 \\
\hline $1987-88$ & 58.60 & 53.42 & 32.53 & 0.54 & 5.83 & 0 \\
\hline $1988-89$ & 41.02 & 50.8 & 26.24 & 0.03 & 4.68 & 0.06 \\
\hline $1989-90$ & 41.55 & 50.01 & 26.85 & 0.01 & 8.53 & 0.6 \\
\hline 1990-91 & 46.45 & 57.21 & 9.4 & 0.01 & 0.7 & 0.08 \\
\hline $1991-92$ & 44.39 & 34.46 & 12.07 & 0.06 & 0.86 & 0.16 \\
\hline $1992-93$ & 34.94 & 32.95 & 9.33 & 0.08 & 0.13 & 0.17 \\
\hline 1993-94 & 25.12 & 53.19 & 7.07 & 0.02 & 2.54 & 0.11 \\
\hline 1994-95 & 39.27 & 31.26 & 7.1 & 0.03 & 0.41 & 0.15 \\
\hline $1995-96$ & 41.57 & 28.19 & 7.42 & 0.01 & 0.97 & 0.03 \\
\hline 1996-97 & 41.32 & 72.4 & 11.08 & 0.03 & 1.6 & 0.01 \\
\hline 1997-98 & 38.61 & 63.4 & 10.97 & 0.05 & 7.62 & 5.08 \\
\hline 1998-99 & 51.13 & 68.2 & 15 & 0.00 & 22.74 & 7.71 \\
\hline 1999-00 & 64.80 & 92.02 & 31.5 & 0.01 & 10.57 & 5.47 \\
\hline $2000-01$ & 49.72 & 64.38 & 28.01 & 0.03 & 7.83 & 2.94 \\
\hline 2001-02 & 49.06 & 75.44 & 27.16 & 0.03 & 4.23 & 2.83 \\
\hline $2002-03$ & 54.23 & 55.14 & 22.34 & 0.11 & 3.34 & 2.61 \\
\hline 2003-04 & 54.74 & 57.16 & 31.82 & 0.11 & 3.55 & 2.01 \\
\hline 2004-05 & 73.08 & 50.99 & 19.25 & 0.02 & 1.98 & 1.26 \\
\hline $2005-06$ & 82.55 & 55.92 & 32.3 & 0.18 & 2.49 & 0.8 \\
\hline $2006-07$ & 69.02 & 51.87 & 18.49 & 0.15 & 0.62 & 7.25 \\
\hline $2007-08$ & 78.78 & 40.83 & 22 & 0.14 & 2.64 & 5.79 \\
\hline 2008-09 & 74.01 & 50.75 & 20.5 & 0.94 & 1.67 & 9.49 \\
\hline $2009-10$ & 87.06 & 50.39 & 21.21 & 1.25 & 6.29 & 11.23 \\
\hline $2010-11$ & 97.08 & 52.96 & 24.32 & 2.14 & 10.26 & 16.74 \\
\hline $2011-12$ & 68.87 & 72.89 & 23.88 & 1.85 & 2.6 & 19.28 \\
\hline 2012-13 & 62.06 & 67.14 & 26.33 & 2.68 & 5.56 & 22.08 \\
\hline $\begin{array}{l}\text { Average } 1980-81 \text { to } \\
2012-13\end{array}$ & 58.24 & 50.30 & 26.57 & 0.46 & 5.96 & 3.85 \\
\hline
\end{tabular}

Source: Authors analysis based on Economic Surveys 1980-2013, Annual Plans 1980-2013, Agriculture Statistics of Pakistan and FAO Statistics. 


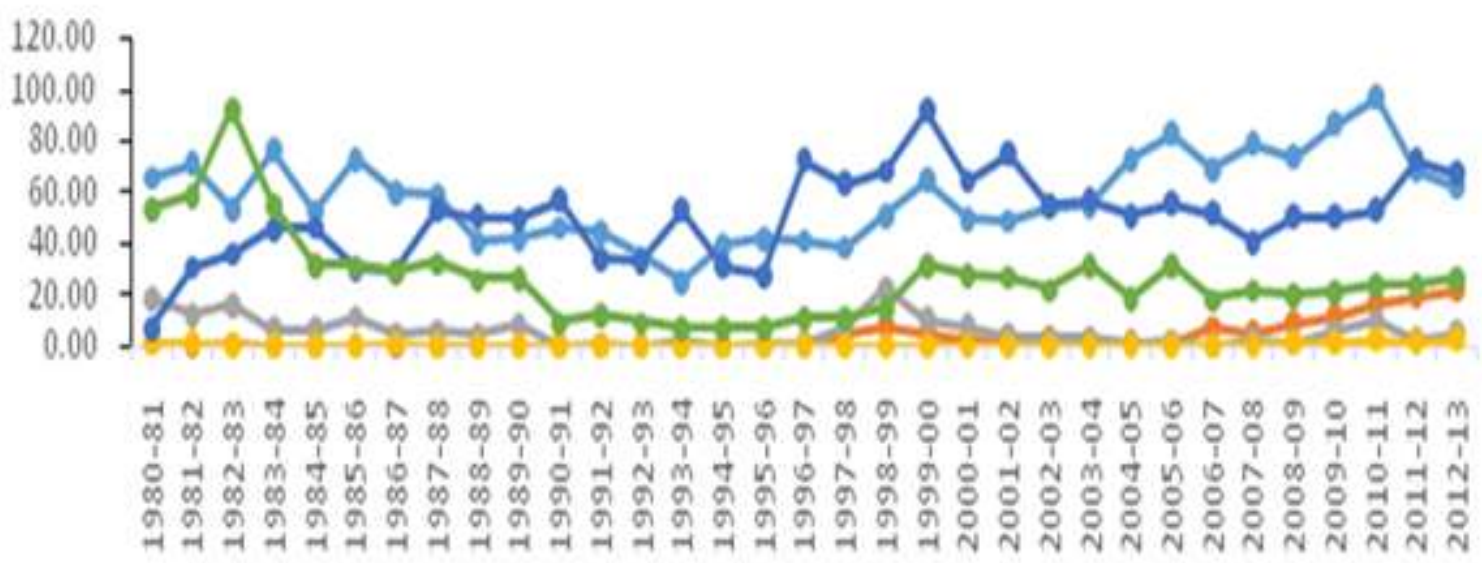

Figure 1. RCA of selected Agriculture Commodities in Pakistan

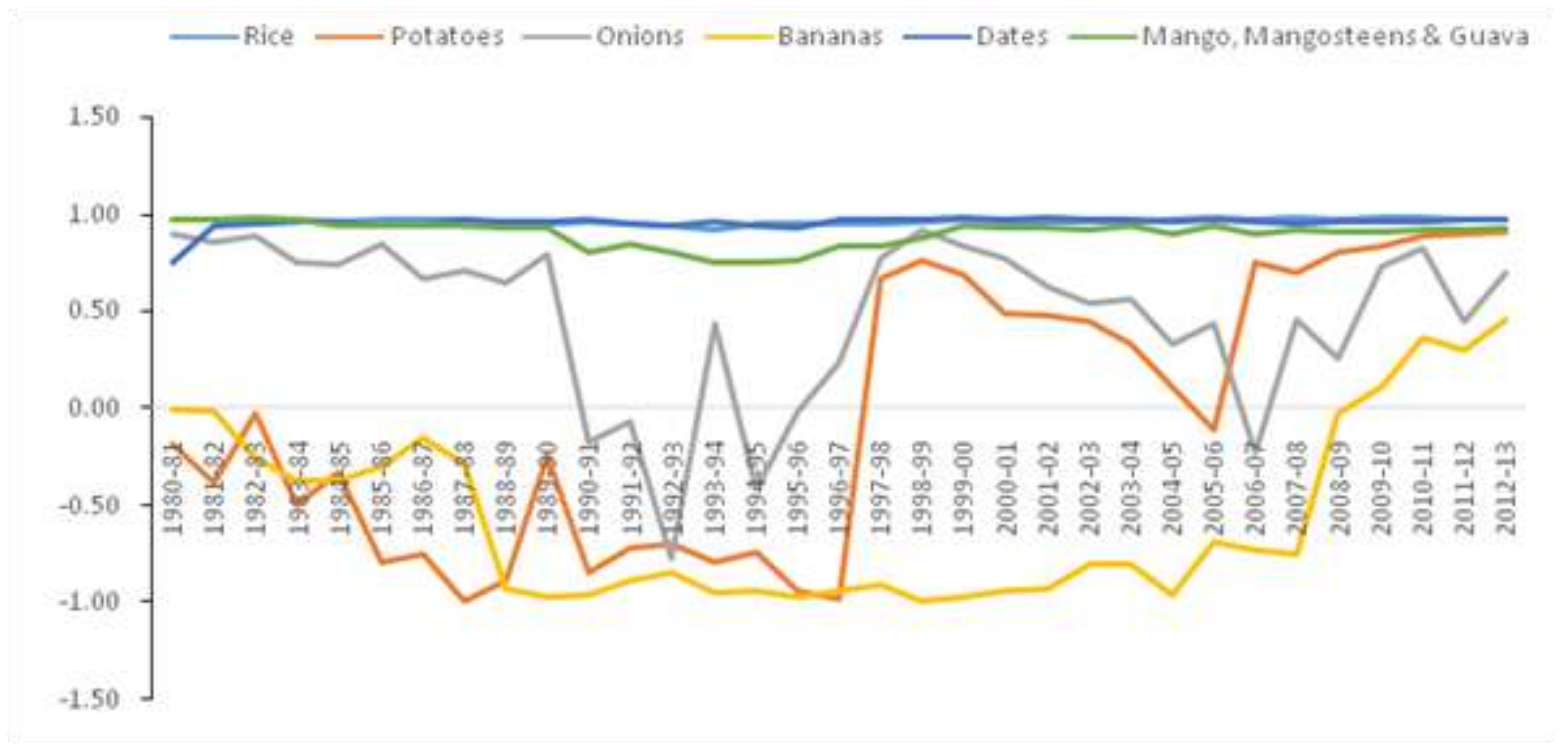

Figure 2. RSCA of selected Agriculture Commodities in Pakistan

Pakistan is the leading exporter of mangoes, mangoes-teens and guava (TDAP, 2010). The results revealed that mango, mangos-teens and guava's revealed comparative advantage has increased over time during the period under analysis (Table1) (Figure 1).

The overall average of revealed comparative advantage of selected agricultural commodities (rice, potatoes, onions, bananas, dates, and mango, mangos-teens and guava) is 58.24, $3.85,5.96,0.46,50.30$ and 26.57 , respectively from 1980 to 2013 . The average of rice and date is greater than that of others and above 50 . The average of other commodities is lower due to having revealed comparative disadvantage in some years of analysis.

RSCA trend depicts that Pakistan has increased specialization in the export of rice, onions, dates and mangos, mangos-teens and guava. Pakistan has increased specialization in the export of potato and banana in the last few years (1997-05 and 2006-13); which is also demonstrated in Figure 2.and Table 2. 
Table 2. Revealed Symmetric Comparative Advantage of selected agricultural commodities of Pakistan

\begin{tabular}{|l|l|l|l|l|l|l|}
\hline Year & Rice & Dates & $\begin{array}{l}\text { Mango, Mango- } \\
\text { teens and Guava }\end{array}$ & Bananas & Potato & Onion \\
\hline $1980-81$ & 0.97 & 0.75 & 0.96 & 0 & -0.18 & 0.9 \\
\hline $1981-82$ & 0.97 & 0.94 & 0.97 & -0.02 & -0.39 & 0.85 \\
\hline $1982-83$ & 0.96 & 0.95 & 0.98 & -0.26 & -0.03 & 0.88 \\
\hline $1983-84$ & 0.97 & 0.96 & 0.96 & -0.37 & -0.5 & 0.75 \\
\hline $1984-85$ & 0.96 & 0.96 & 0.94 & -0.37 & -0.33 & 0.74 \\
\hline $1985-86$ & 0.97 & 0.94 & 0.94 & -0.3 & -0.8 & 0.84 \\
\hline $1986-87$ & 0.97 & 0.94 & 0.93 & -0.15 & -0.76 & 0.66 \\
\hline $1987-88$ & 0.97 & 0.96 & 0.94 & -0.3 & -1 & 0.71 \\
\hline $1988-89$ & 0.95 & 0.96 & 0.93 & -0.94 & -0.89 & 0.65 \\
\hline $1989-90$ & 0.95 & 0.96 & 0.93 & -0.98 & -0.25 & 0.79 \\
\hline $1990-91$ & 0.96 & 0.97 & 0.81 & -0.97 & -0.85 & -0.18 \\
\hline $1991-92$ & 0.96 & 0.94 & 0.85 & -0.89 & -0.73 & -0.08 \\
\hline $1992-93$ & 0.94 & 0.94 & 0.81 & -0.86 & -0.71 & -0.78 \\
\hline $1993-94$ & 0.92 & 0.96 & 0.75 & -0.96 & -0.8 & 0.43 \\
\hline $1994-95$ & 0.95 & 0.94 & 0.75 & -0.95 & -0.75 & -0.42 \\
\hline $1995-96$ & 0.95 & 0.93 & 0.76 & -0.98 & -0.94 & -0.02 \\
\hline $1996-97$ & 0.95 & 0.97 & 0.83 & -0.95 & -0.99 & 0.23 \\
\hline $1997-98$ & 0.95 & 0.97 & 0.83 & -0.91 & 0.67 & 0.77 \\
\hline $1998-99$ & 0.96 & 0.97 & 0.88 & -1 & 0.77 & 0.92 \\
\hline $1999-00$ & 0.97 & 0.98 & 0.94 & -0.98 & 0.69 & 0.83 \\
\hline $2000-01$ & 0.96 & 0.97 & 0.93 & -0.94 & 0.49 & 0.77 \\
\hline $2001-02$ & 0.96 & 0.97 & 0.93 & -0.94 & 0.48 & 0.62 \\
\hline $2002-03$ & 0.96 & 0.96 & 0.91 & -0.81 & 0.45 & 0.54 \\
\hline $2003-04$ & 0.96 & 0.97 & 0.94 & -0.81 & 0.34 & 0.56 \\
\hline $204-05$ & 0.97 & 0.96 & 0.9 & -0.97 & 0.11 & 0.33 \\
\hline $2005-06$ & 0.98 & 0.96 & 0.94 & -0.69 & -0.11 & 0.43 \\
\hline $2006-07$ & 0.97 & 0.96 & 0.9 & -0.73 & 0.76 & -0.23 \\
\hline $2007-08$ & 0.97 & 0.95 & 0.91 & -0.75 & 0.71 & 0.45 \\
\hline $2008-09$ & 0.97 & 0.96 & 0.91 & -0.03 & 0.81 & 0.25 \\
\hline $2009-10$ & 0.98 & 0.96 & 0.91 & 0.11 & 0.84 & 0.73 \\
\hline $2010-11$ & 0.98 & 0.96 & 0.92 & 0.36 & 0.89 & 0.82 \\
\hline $2011-12$ & 0.97 & 0.97 & 0.92 & 0.3 & 0.9 & 0.44 \\
\hline $2012-13$ & 0.97 & 0.97 & 0.93 & 0.46 & 0.91 & 0.7 \\
\hline Average $1980-$ & 0.96 & 0.95 & 0.90 & -0.56 & -0.04 & 0.48 \\
\hline 81 to 2012-13 & & & & & \\
\hline & & & & & \\
\hline
\end{tabular}

Source: Authors analysis based on Economic surveys 1980-2013, Annual Plans 1980-2013, Agriculture statistics of Pakistan and FAO Statistics.

\section{CONCLUSION}

Based on the analysis of selected agricultural export commodities of Pakistan during the period (1980-2013), the study concludes that Pakistan has a high degree of comparative and competitive advantage in rice, dates and mangoes. If the export of the above-mentioned commodities is increased and maintained according to the international standards, these agricultural products may significantly be contributed to reduce the trade deficit to a certain extent. Pakistan has also experienced a comparative dis-advantage in the export of onions, bananas and potatoes during 19802013, and the situation was gradually transformed into comparative advantage a few years ago. During the mentioned period, Pakistan has enhanced its specialization in export, which implies that Pakistan is more likely to continue its comparative and competitive advantages in exports of all commodities under consideration. In order to increase and retain the competitiveness in onion, banana, and potato exports, the government should formulate policies for the improvement of technology to meet the marketable demand. Moreover, there is a dire need to formulate international marketing policies so that these commodities can also make a considerable contribution to reduce overall negative trade balance of Pakistan.

\section{Conflict of interest}

It is hereby declared by the authors that there is no potential conflict of interest with respect to research, financial relationship, authorship, and/or publication of this article.

\section{AUTHOR'S CONTRIBUTION}

A. Ali: Conceived the idea and conducted the field study

W. Akhtar: Analyzed the collected data

S. Ahmad: Wrote the draft of the paper

C. Honghua: Reviewed and done the proof reading 


\section{REFERENCES}

Akhtar, S., S. Ramzan, S. Ahmad, W. Huifang, S. Imran and H. Yousaf. 2018. Women in Agriculture- Lack of access to resources (An analytical study of district Faisalabad, Punjab, Pakistan). SSRG International Journal of Economics Management Studies.

Akhtar, W., M. Sharif and H. Shah. 2009. Competitiveness of Pakistani fruits in the world Market. The Lahore Journal of Economics, 14 (2): 125-133.

Akhtar, W., M. Sharif and N. Akmal. 2007. Analysis of Economic efficiency and competitiveness of the rice production system of Pakistan's Punjab. The Lahore Journal of Economics 12 (1): 141-153.

Akhtar, W., N. Akmal, H. Shah, M. A. Niazi and A. Tahir. 2013. Export competitiveness of Pakistani horticulture products. Pakistan Journal of Agriculture Research, 26 (2): 87-96.

Ali, S. 2013. Top 10 Exporters of rice (Countries). Retrieved on January 5, 2020 from https://www.countriesnow.com/top-10exporters-of-rice.

Balassa, B. 1965. Trade liberalisation and revealed comparative advantage. The Manchester School, 33 (2): 99-123.

Balassa, B. 1989. Comparative advantage, trade policy and economic development. London: Harvester Wheatsheaf.

Dalum, B., K. Laursen and G. Villumsen. 1998. Structural change in oecd export specialisation patterns:de-specialisation and 'Stickiness'. International Review of Applied Economics, 12 (3): 447-467.

Ferto, I. and L. J. Hubbard. 2004. The dynamics of Agri-Food Trade patterns. The accession countries' case. Seventy Eighth Annual Conference of the Agricultural Economics Society, Imperial College, London. pp. 2-4.

Ishtiaq, M., A. Tariq and A. Khalid. 1988. Physical properties of the fruit of some indigenous date palm cultivars grown at D. I. Khan. Sarhad Journal of Agriculture, 4 (3): 271- 274.

Khadim, I. 2016. Most exported fruits and vegetable from Pakistan. Retrieved on January 5, 2020 from https://wowreads.com/ exported-fruits-vegetable-pakistan.

Laursen. K. 1998. Revealed comparative advantage and the alternatives as measures of international specialization. DRUID
Working Paper No. 98-30, Copenhagen Business School, Department of Industrial Economics and Strategy/ Aalborg University, Department of Business Studies.

Mahmoud, B. and A. H. Zadeh. 2012. Comparative advantage of selected agricultural products in Iran: A Revealed Comparative Advantage Assessment. World Applied Sciences Journal, 19 (10): 14491452.

Markhand, G. S., A. A. Abul-Soad, A. A. Mirbahar and N. A. Kanhar. 2010. Fruit characterization of Pakistani dates. Pakistan Journal of Botany, 42 (6): 3715-3722.

Memon, N. A. 2015. Bananas: Natural Medicine for digestive, depression and more. Pakistan Food Journal, pp. 22-25.

Ruma, B. 2011. Revealed comparative advantage and competitiveness: A case study for India in horticultural products. International Conference on Applied Economics-ICOAE.

Selim, H. H. A., M. A. M. Mahdi and M. S. ElHakeem. 1970. Studies on the evaluation of fifteen local date cvs grown under desert condition in Siwa Oasis, U.A.R. Bull. De I'Inst. Du Desert d'Egypte, 18 (2): 137-155.

Tabasam, N., A. Arshad, S. Ahmad and S. Akhtar. 2018. Factors Affecting the Scenario of Women Participation in the Agricultural Labor Force in Punjab, Pakistan. Saudi Journal of Economics and Finance 2 (5): 251-256.

TDAP, 2010. A report on mangoes: Prepared by TDAP Multan Office.

Vijayasri, G. V. 2013. The importance of international trade in the World. International Journal of Marketing, Financial Services and Management Research, 2 (9): 111-119.

Vollrath, T. L. 1991. A Theoretical evaluation of alternative trade intensity measures of revealed comparative advantage. Welt wirtschaftliches Archiv., 127 (2): 265-280.

Workman, D. 2019. World's top export: bananas exports by country. Retrieved on January 5 , 2020 from http://www. worldstopexports.com/ bananas-exports-country/

Yousaf, H., M. U. Zafar, M. O. Zafar, S. Ahmad and Q. A. Raza. 2018. Regional distribution of food security and its determinants across regions of the Punjab. Pakistan Journal of Agricultural Sciences, 55 (3): 705-711.

(Received: March 17, 2019; Accepted: January 01, 2020) 